\title{
Leachability of metals from gold tailings by rainwater: an experimental and geochemical modelling approach
}

\author{
BPC Grover', RH Johnson ${ }^{2}$ and H Tutu ${ }^{1 *}$ \\ 'Molecular Sciences Institute, School of Chemistry, University of the Witwatersrand, Johannesburg, South Africa \\ ${ }^{2}$ SM Stoller Corporation, Grand Junction, CO 81503, USA
}

\begin{abstract}
Mine leachates from gold tailings impoundments usually contain elevated concentrations of metals and sulphates that impact negatively on water quality. This study was aimed at assessing the leachability of such metals from tailings by rainwater. Oxidised and unoxidised tailings were leached experimentally and through simulations using the PHREEQC geochemical modelling code. The results revealed that the majority of readily leachable metals were held in secondary mineral phases, mainly sulphates. A good agreement between experimental and modelling techniques was obtained, indicating the potential use of geochemical modelling in future metal release studies for the site. A list of reactive minerals for the tailings material was compiled. These minerals may or may not be present in the tailings; however, the list provides a means of estimating future reactivity or bulk metal release from the tailings.
\end{abstract}

\section{INTRODUCTION}

Gold tailings in the Witwatersrand Basin, South Africa, are known to contain elevated amounts of trace elements that can potentially leach into the surrounding soils and water systems (Camden-Smith et al., 2013; Tutu, 2006). Acid mine drainage (AMD) has been a major challenge in the area owing to the oxidation of remnant pyrite $\left(\mathrm{FeS}_{2}\right)$ in the tailings, resulting in mobilisation of metals and large quantities of sulphate. Rainwater is the major source of oxygenated water that is responsible for the oxidation process, depicted by the following simplified equations (Stumm and Morgan, 1996):

$$
\begin{aligned}
& \mathrm{FeS}_{2}+3.5 \mathrm{O}_{2}+\mathrm{H}_{2} \mathrm{O} \rightarrow \mathrm{Fe}^{2+}+2 \mathrm{SO}_{4}^{2-}+2 \mathrm{H}^{+} \\
& \mathrm{Fe}^{2+}+0.25 \mathrm{O}_{2}+\mathrm{H}^{+} \rightarrow \mathrm{Fe}^{3+}+0.5 \mathrm{H}_{2} \mathrm{O} \\
& \mathrm{FeS}_{2}+14 \mathrm{Fe}^{3+}+8 \mathrm{H}_{2} \mathrm{O} \rightarrow 15 \mathrm{Fe}^{2+}+2 \mathrm{SO}_{4}{ }^{2-}+16 \mathrm{H}^{+}
\end{aligned}
$$

Ferric iron can be removed from solution at $\mathrm{pH}$ values $>3$ by hydrolysis according to the following reaction:

$$
\mathrm{Fe}^{3+}+3 \mathrm{H}_{2} \mathrm{O} \rightarrow \mathrm{Fe}(\mathrm{OH})_{3}+3 \mathrm{H}^{+}
$$

There is a range of bacteria, including Thiobacillus ferroxidans, which play a major role in catalysing the oxidation process (Nordstrom and Southam, 1997). The released acidity $\left(\mathrm{H}^{+}\right)$is responsible for the mobilisation of trace elements such as arsenic, iron, lead, copper, cobalt, manganese, nickel, zinc and uranium that constitute the tailings host ores (Blowes et al., 2003). Following the release of these elements and sulphates, secondary minerals that range from simple sulphate salts to complex multielement sulphates usually form along the flow path (Jambor et al., 2000). Later percolation of rainwater during a different rainy season can result in fresh oxidation reactions as well as dissolution of these secondary salts, resulting in pollutant plumes that can impact on soils and receiving water systems.

\footnotetext{
* To whom all correspondence should be addressed.

e-mail: hlanganani.tutu@wits.ac.za

Received: 2 April 2015; accepted in revised form 13 November 2015
}

This study used a combination of laboratory-based leaching experiments and geochemical modelling to assess the leachability of elements, and the mineral phases responsible for their release, from oxidised and unoxidised material from a partially reprocessed tailings facility. The combination of the two techniques can be used to provide a list of reactive minerals that can be incorporated into models predicting the bulk release of metals from the study site for impact assessment studies.

\section{MATERIALS AND METHODS}

\section{Sampling and analytical procedures}

Oxidised and unoxidised tailings were collected from an abandoned gold mining tailings facility located in the Central Rand of the Witwatersrand Basin. The site (situated near Germiston, Gauteng) was partially reclaimed following reprocessing of tailings. Remnants of tailings have been implicated in the pollution of surrounding soils and water (Tutu et al., 2008; Camden-Smith et al., 2013; Bakatula et al., 2012). Oxidised tailings were taken from the surface of the tailings dump to a depth of about $30 \mathrm{~cm}$ and were yellowish in colour. Unoxidised tailings were dug from the side of the tailings dump, discarding the overlying oxidised material in the process. Unoxidised tailings were grey in colour and were finer grained and closer packed than oxidised tailings. The tailings material was comprised mostly of quartz with other minerals below the detection limit of standard powder X-ray diffraction techniques; hence the need to determine a 'reactive mineralogy' set through the use of geochemical modelling.

For this study, synthetic rainwater was used to leach oxidised tailings while sulphuric acid was used to leach unoxidised tailings. Conceptually, rainwater percolates through oxidised tailings and the resulting leachates (acidic and high in sulphate) infiltrate to the underlying unoxidised tailings (Fig. 1). Synthetic rainwater was prepared at 100 times the required concentration and then subsequently diluted. The concentrated rainwater was prepared in a $1 \mathrm{~L}$ volumetric flask using the following salts: $1.1614 \mathrm{~g} \mathrm{NH}_{4} \mathrm{NO}_{3}, 0.785 \mathrm{~g} \mathrm{~K}_{2} \mathrm{SO}_{4}, 0.1157 \mathrm{~g}$ of $\mathrm{Na}_{2} \mathrm{SO}_{4}, 0.1302 \mathrm{~g}$ of $\mathrm{MgSO}_{4} \cdot 7 \mathrm{H}_{2} \mathrm{O}$ and $0.4484 \mathrm{~g} \mathrm{CaCl}_{2}$ (adapted from Cocksedge, 1988). The sulphuric acid leaching solution was prepared by diluting concentrated sulphuric acid with 


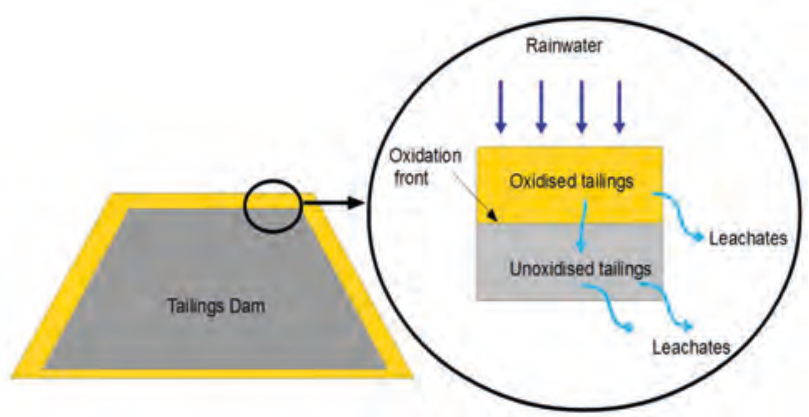

Figure 1

A conceptual section of oxidised and unoxidised tailings showing incoming rainwater interacting with oxidised tailings and the resulting leachates interacting with unoxidised tailings

deionised water until a solution of $\mathrm{pH} 2.9$ was obtained. A Knick 766 Calimatic pH probe (Knick, Germany) was used to measure $\mathrm{pH}$.

Leaching experiments were conducted at room temperature using a ratio of $20 \mathrm{~g}$ of tailings to $400 \mathrm{~m} \ell$ leaching solution. The 20:1 liquid to solid ratio has been used in standard experiments such as the USGS Field Leach Test and Modified USEPA 1312 SLP to determine pollutant release from various matrices (Hageman, 2007). The high ratio ensures that readily soluble minerals remain below their saturation limits in solution and their dissolution is thermodynamically allowed (Hageman, 2007). The flasks were shaken for $24 \mathrm{~h}$ on a shaker and the leachates were filtered using $0.45 \mu \mathrm{m}$ Prima PES filter membranes. Metal and anion contents in the filtrates were determined using inductively coupled plasma- optical emission spectroscopy (ICP-OES, Spectro Genesis, Germany) and chemically suppressed ion chromatography (IC, Metrohm, Switzerland), respectively.

\section{Geochemical modelling}

The analytical results were used to establish speciation-solubility models using the PHREEQC version 3.2 geochemical modelling code (Parkhurst and Appelo, 2013). The Wateq4f database of the code was used. Data for the $\mathrm{Al}_{2}\left(\mathrm{SO}_{4}\right)_{3} \cdot 6 \mathrm{H}_{2} \mathrm{O}$ mineral was imported from the LLNL (Lawrence Livermore National Laboratory) database, which accompanied the software.

Inverse modelling between the blank leaching solutions and final leachates was undertaken to determine the mass transfer of minerals between the solutions. Inverse modelling is also known as mass balance modelling. Given the composition of two related water solutions and the mineralogy of the rock or solid material with which the water interacts, inverse modelling can be used to quantify a set of possible reactants that transformed the first solution into the second (Nordstrom and Campbell, 2014; Šráček et al., 2013). Mass balance equations are utilised and neither thermodynamic properties nor kinetic restraints are considered (Zhu and Anderson, 2002).

Forward modelling was then used to validate the inverse models. In forward modelling, the final composition of a solution after a reaction or equilibration is calculated (Crawford, 1999). Thermodynamic models utilise equilibrium constraints and are assumed to be valid for homogeneous reactions in which there is sufficient residence time for equilibrium to be established. Heterogeneous reactions such as the dissolution and precipitation of minerals as well as adsorption are often kinetically controlled and ideally models should be adjusted accordingly.

Using this method, the models were iteratively altered until modelled simulations correlated with experimental results. The selection of minerals for inverse modelling requires knowledge of the mineralogy of the tailings in contact with the solution. Typical PHREEQC version 3.2 scripts for the inverse models used are shown in Fig. 2. The solutions were defined using a ssolution spread) function, complete data for solution input is summarised in the tables comparing the actual and simulated results in Table 2 and Table 4 . The models were constructed such that a mineral which was oversaturated was not allowed to dissolve into solution. Similarly, if a mineral was undersaturated it was not allowed to precipitate. For the forward reactions, the «equilibrium phases function was used. A typical PHREEQC version 3.2 script for this type of forward model is shown in Fig. 3. In this case, the 'equilibrium phases' function yielded the same results as the 'reaction' function because minerals remained undersaturated. The 〈reaction〉 function will force the dissolution

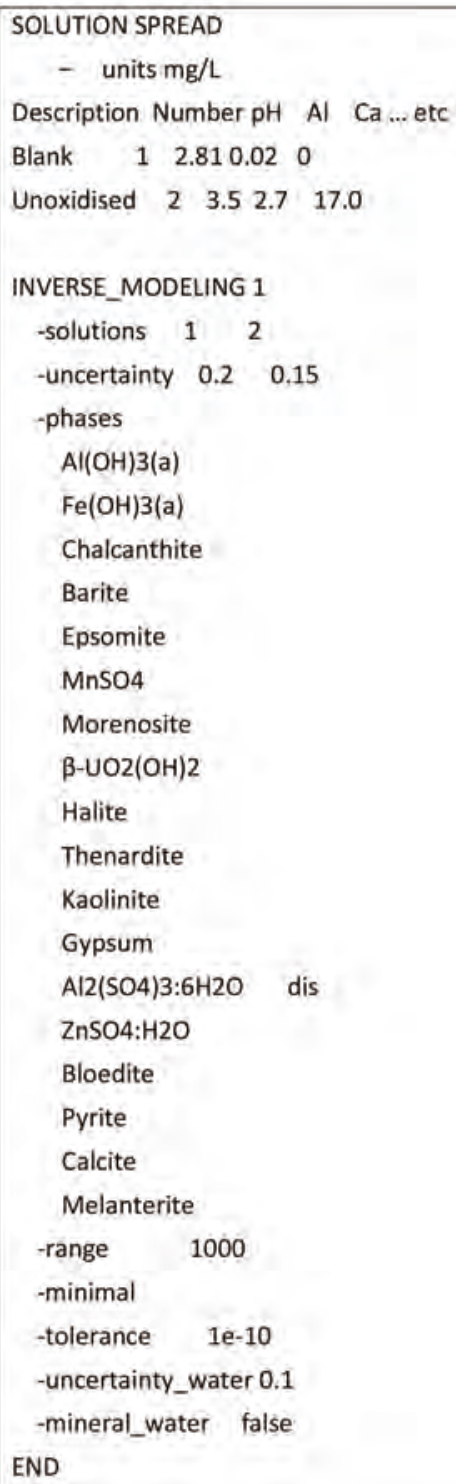

Figure 2

PHREEQC version 3.2 input for the inverse model between blank and unoxidised tailings sulphuric acid leachate 


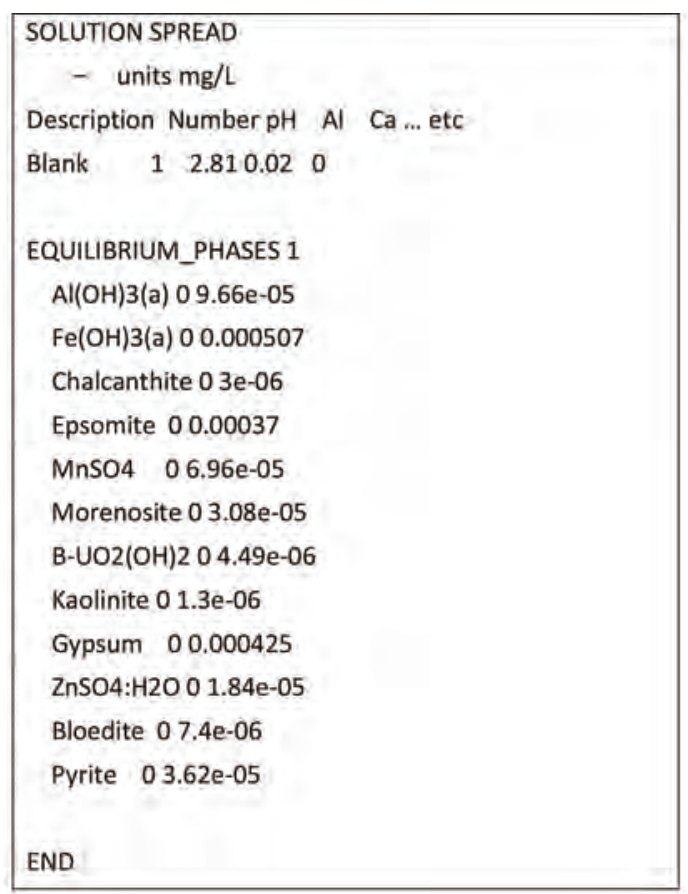

Figure 3

PHREEQC version 3.2 input for forward model using the EQUILIBRIUM PHASES function

of minerals that are supersaturated and as such was not used for this model. Kinetic modelling was not used in this study. The leaching experiments took place over $24 \mathrm{~h}$ and, given the high liquid to solid ratio, it was assumed that readily soluble minerals would have dissolved during this time.

Based on other studies in the region (Nengovhela et al., 2006; Tutu et al., 2008), it was assumed that the oxidised section of tailings materials contains secondary sulphate minerals such as jarosite and gypsum. The model simulations for the oxidised tailings were based on the assumption that, since it is not a strong leaching solution, rainwater would be expected to target mainly the readily soluble (i.e. the water- and acid-soluble) mineral phases of the oxidised tailings. As such, the minerals selected for inverse modelling are mostly hydrated sulphate minerals, such as gypsum $\left(\mathrm{CaSO}_{4} \cdot 2 \mathrm{H}_{2} \mathrm{O}\right)$ and pickeringite $\left(\mathrm{MgAl}_{2}\left(\mathrm{SO}_{4}\right)_{4} \cdot 22 \mathrm{H}_{2} \mathrm{O}\right)$. The minor elements might be included in the bulk sulphate minerals through solid solution. However, in the model they have been described as pure members. On the other hand, since sulphuric acid is a stronger leaching solution, it was expected that it would dissolve fractions that were both readily soluble and not readily soluble. Unoxidised tailings, which may be partially oxidised, would be expected to contain iron in both an oxidised and reduced state. Therefore, in the model iron has been added as both ferric hydroxide $\left(\mathrm{Fe}(\mathrm{OH})_{3}\right)$ and pyrite $\left(\mathrm{FeS}_{2}\right)$. Pyrite was also observed in unoxidised tailings by Nengovhela et al. (2006) and was not present in the upper, oxidised portion of tailings dams.

\section{RESULTS AND DISCUSSION}

\section{Leaching of oxidised tailings}

In a study by Grover et al. (2015, unpublished) at the same site, the European Communities Bureau of Reference (BCR) threestep sequential extraction procedure (Rauret et al., 1999) was used for oxidised tailings. The results showed that these tailings contained aluminium $(\mathrm{Al})$, copper $(\mathrm{Cu})$, cobalt $(\mathrm{Co})$, calcium $(\mathrm{Ca})$, magnesium $(\mathrm{Mg})$, manganese $(\mathrm{Mn})$, nickel $(\mathrm{Ni})$ and zinc $(\mathrm{Zn})$, which were mostly present in a readily soluble fraction. This fraction was found to contain elevated sulphate concentrations, suggesting that the metals were sulphate salts. At similar sites in the region, Cukrowska et al. (2004) have found that the mobilities of $\mathrm{Al}, \mathrm{Ca}, \mathrm{Co}, \mathrm{Cr}, \mathrm{Cu}, \mathrm{Fe} \mathrm{Mg}, \mathrm{Mn}, \mathrm{Ni}$ and $\mathrm{Zn}$ increased during a second leaching with an acidic rainwater solution ( $\mathrm{pH}$ 4.2). This finding supports the decision to use readily soluble phases as minerals of interest in the inverse models.

In our study, iron was mostly present in a reducible phase, possibly hydroxides and oxyhydroxides. The formation of iron hydroxides from pyrite is represented by the reactions summarised by Stumm and Morgan (1996) earlier in the text.

While uranium was not detected in the sequential leaching process of the oxidised tailings, it was found to exist in a reducible phase in the unoxidised tailings. Based on these findings, sulphate minerals, amorphous iron hydroxide and uranyl hydroxide were defined as phases for inverse modelling. Table 1 includes the mineral names and formulae used in inverse modelling, the action (precipitated or dissolved) and the amount (expressed in moles) transferred. Precipitated minerals have left the solution and are assumed to be incorporated into the solid residue or suspended in solution. Dissolved minerals have entered the solution from the solid material and their components exist as soluble species in the final solution. The iterated simulation revealed that two additional phases, namely $\mathrm{FeSO}_{4}$ and $\mathrm{Al}(\mathrm{OH})_{3}$, were required for the model to converge. At the measured redox (pe) conditions, the iron in the oxidised tailings leachate was found to exist primarily as a mobile ferrous $\left(\mathrm{Fe}^{2+}\right)$ phase and as such the addition of a ferrous salt (e.g. $\mathrm{FeSO}_{4}$ ) was required. The second additional phase required was amorphous $\mathrm{Al}(\mathrm{OH})_{3}$, the addition of which led to the lowering of the $\mathrm{pH}$ of the system as a result of precipitation.

\begin{tabular}{|c|c|c|c|}
\hline \multicolumn{4}{|c|}{$\begin{array}{c}\text { TABLE } 1 \\
\text { Minerals predicted by inverse modelling for transfers } \\
\text { between the oxidised tailings and the synthetic rainwater } \\
\text { leaching solution }\end{array}$} \\
\hline Mineral & Formula & Action & $\begin{array}{c}\text { Amount } \\
\text { (moles) }\end{array}$ \\
\hline $\mathrm{Al}(\mathrm{OH})_{3}(\mathrm{a})$ & $\mathrm{Al}(\mathrm{OH})_{3}$ & Precipitate & $7.90 \times 10^{-5}$ \\
\hline Alum K & $\mathrm{KAl}\left(\mathrm{SO}_{4}\right)_{2} \cdot 12 \mathrm{H}_{2} \mathrm{O}$ & Dissolve & $1.24 \times 10^{-4}$ \\
\hline Barite & $\mathrm{BaSO}_{4}$ & Dissolve & $3.41 \times 10^{-8}$ \\
\hline$\beta-\mathrm{UO}_{2}(\mathrm{OH})_{2}$ & $\mathrm{UO}_{2}(\mathrm{OH})_{2}$ & Dissolve & $6.89 \times 10^{-7}$ \\
\hline Chalcanthite & $\mathrm{CuSO}_{4} \cdot 5 \mathrm{H}_{2} \mathrm{O}$ & Dissolve & $5.47 \times 10^{-6}$ \\
\hline Epsomite & $\mathrm{MgSO}_{4} \cdot 7 \mathrm{H}_{2} \mathrm{O}$ & Dissolve & $1.51 \times 10^{-4}$ \\
\hline Goslarite & $\mathrm{ZnSO}_{4} \cdot 7 \mathrm{H}_{2} \mathrm{O}$ & Dissolve & $2.88 \times 10^{-6}$ \\
\hline Gypsum & $\mathrm{CaSO}_{4} \cdot 2 \mathrm{H}_{2} \mathrm{O}$ & Precipitate & $2.60 \times 10^{-5}$ \\
\hline Halite & $\mathrm{NaCl}$ & Dissolve & $3.40 \times 10^{-4}$ \\
\hline Kaolinite & $\mathrm{Al}_{2} \mathrm{Si}_{2} \mathrm{O}_{5}(\mathrm{OH})_{4}$ & Dissolve & $5.22 \times 10^{-7}$ \\
\hline Melanterite & $\mathrm{FeSO}_{4} \cdot 7 \mathrm{H}_{2} \mathrm{O}$ & Dissolve & $3.22 \times 10^{-6}$ \\
\hline $\mathrm{MnSO}_{4}$ & $\mathrm{MnSO}_{4}$ & Dissolve & $1.21 \times 10^{-5}$ \\
\hline Morenosite & $\mathrm{NiSO}_{4} \cdot 7 \mathrm{H}_{2} \mathrm{O}$ & Dissolve & $1.73 \times 10^{-5}$ \\
\hline Pickeringite & $\mathrm{MgAl}_{2}\left(\mathrm{SO}_{4}\right)_{4} \cdot 22\left(\mathrm{H}_{2} \mathrm{O}\right)$ & Dissolve & $4.29 \times 10^{-4}$ \\
\hline Thenardite & $\mathrm{Na}_{2} \mathrm{SO}_{4}$ & Precipitate & $1.67 \times 10^{-4}$ \\
\hline
\end{tabular}


The inverse model was verified by creating a forward model in which the minerals (solid reactants) were added to the initial rainwater solution. The precipitation of gypsum led to the removal of calcium from the original leaching solution, resulting in a lower concentration of calcium in the predicted model. Experimental and final simulated model results for rainwater leachates for oxidised tailings are presented in Table 2 . The results showed that the experimental and modelled results agreed within $5 \%$.

\section{Leaching of unoxidised tailings}

Readily soluble sulphate minerals were selected as phases for simulating the leaching of unoxidised tailings with dilute sulphuric acid. However, sequential extractions had shown that aluminium in unoxidised tailings was associated with the reducible phase (hydroxides and oxides) of the tailings and only a small percentage was present as a readily soluble phase. Aluminium hydroxide $\left(\mathrm{Al}(\mathrm{OH})_{3}\right)$ is formed following the dissolution of aluminosilicates such as kaolinite and in reactive transport simulations it has been shown that a portion of aluminium will be transported in contaminant plumes as a sulphate phase such alunite (Šráček et al., 2013). As such, aluminium was associated with the hydroxide phase for the modelling of the unoxidised tailings. The oxic and acidic conditions were expected to encourage the oxidation of pyrite present in the unoxidised material. Therefore, pyrite was selected as a mineral of interest along with iron, uranium and aluminium hydroxides, and readily soluble salts for inverse and forward modelling (Table 3).

The inverse model was verified by creating a forward model in which the solid reactants were added to the initial sulphuric acid solution. Experimental and final simulated model results for the sulphuric acid leachates for unoxidised tailings are presented in Table 4 . The results showed that the two agreed

TABLE 2

Composition of analysed rainwater leachates versus modelled rainwater solution (units for elements in molality)

\begin{tabular}{|c|c|c|}
\hline Analyte & Experimental & Simulated \\
\hline $\mathrm{pH}$ & 3.6 & 3.604 \\
\hline pe & 7.35 & 7.17 \\
\hline Ionic strength & $5.87 \times 10^{-3}$ & $6.00 \times 10^{-3}$ \\
\hline $\mathrm{Al}$ & $9.05 \times 10^{-4}$ & $9.05 \times 10^{-4}$ \\
\hline $\mathrm{Ba}$ & $7.77 \times 10^{-8}$ & $7.78 \times 10^{-8}$ \\
\hline $\mathrm{Ca}$ & Not detected & $2.32 \times 10^{-8}$ \\
\hline $\mathrm{Cl}$ & $4.09 \times 10^{-4}$ & $4.09 \times 10^{-4}$ \\
\hline $\mathrm{Cu}$ & $5.64 \times 10^{-6}$ & $5.64 \times 10^{-6}$ \\
\hline $\mathrm{Fe}$ & $3.22 \times 10^{-6}$ & $3.22 \times 10^{-6}$ \\
\hline K & $1.71 \times 10^{-4}$ & $1.97 \times 10^{-4}$ \\
\hline $\mathrm{Mg}$ & $5.86 \times 10^{-4}$ & $5.86 \times 10^{-4}$ \\
\hline $\mathrm{Mn}$ & $1.21 \times 10^{-5}$ & $1.21 \times 10^{-5}$ \\
\hline $\mathrm{Na}$ & $1.96 \times 10^{-5}$ & $2.00 \times 10^{-5}$ \\
\hline $\mathrm{Ni}$ & $1.73 \times 10^{-5}$ & $1.73 \times 10^{-5}$ \\
\hline S & $1.85 \times 10^{-3}$ & $2.00 \times 10^{-3}$ \\
\hline $\mathrm{Si}$ & $1.65 \times 10^{-6}$ & $1.65 \times 10^{-6}$ \\
\hline $\mathrm{U}$ & $6.89 \times 10^{-7}$ & $6.89 \times 10^{-7}$ \\
\hline $\mathrm{Zn}$ & $2.88 \times 10^{-6}$ & $2.88 \times 10^{-6}$ \\
\hline
\end{tabular}

within $5 \%$ except for the redox potential (pe) and potassium concentration. In this model, no potassium-bearing mineral was defined as inclusion of the aluminium-potassium sulphate mineral $\left(\mathrm{KAl}\left(\mathrm{SO}_{4}\right)_{2} \cdot 12 \mathrm{H}_{2} \mathrm{O}\right)$ altered the aluminium equilibrium and therefore the $\mathrm{pH}$ of the solution. Furthermore, given the strong leaching solution, the potassium could have leached from silicates. The potassium value in the blank leaching solution was $0.32 \mathrm{mg} / \mathrm{L}$ and in the final solution was $0.40 \mathrm{mg} / \mathrm{L}$. Given the small difference and the uncertainty in the origin of the potassium, it was decided to exclude potassium from the inverse model.

\begin{tabular}{|c|c|c|c|}
\hline \multicolumn{4}{|c|}{$\begin{array}{c}\text { TABLE } 3 \\
\text { Minerals predicted by inverse modelling for transfers } \\
\text { between the unoxidised tailings and the sulphuric acid } \\
\text { leaching solution }\end{array}$} \\
\hline Mineral & Formula & Action & $\begin{array}{l}\text { Amount } \\
\text { (moles) }\end{array}$ \\
\hline $\mathrm{Al}(\mathrm{OH})_{3}(\mathrm{a})$ & $\mathrm{Al}(\mathrm{OH})_{3}$ & Dissolve & $9.66 \times 10^{-5}$ \\
\hline Bloedite & $\mathrm{Na}_{2} \mathrm{Mg}\left(\mathrm{SO}_{4}\right)_{2} \cdot 2 \mathrm{H}_{2} \mathrm{O}$ & Dissolve & $7.40 \times 10^{-6}$ \\
\hline$\beta-\mathrm{UO}_{2}(\mathrm{OH})_{2}$ & $\mathrm{UO}_{2}(\mathrm{OH})_{2}$ & Dissolve & $4.49 \times 10^{-6}$ \\
\hline Chalcanthite & $\mathrm{CuSO}_{4} \cdot 5 \mathrm{H}_{2} \mathrm{O}$ & Dissolve & $3.00 \times 10^{-6}$ \\
\hline Epsomite & $\mathrm{MgSO}_{4} \cdot 7 \mathrm{H}_{2} \mathrm{O}$ & Dissolve & $3.70 \times 10^{-4}$ \\
\hline $\mathrm{Fe}(\mathrm{OH})_{3}(\mathrm{a})$ & $\mathrm{Fe}\left(\mathrm{OH}_{3}\right)$ & Dissolve & $5.07 \times 10^{-4}$ \\
\hline Gypsum & $\mathrm{CaSO}_{4} \mathrm{v} 2 \mathrm{H}_{2} \mathrm{O}$ & Dissolve & $4.25 \times 10^{-4}$ \\
\hline Kaolinite & $\mathrm{Al}_{2} \mathrm{Si}_{2} \mathrm{O}_{5}(\mathrm{OH})_{4}$ & Dissolve & $1.30 \times 10^{-6}$ \\
\hline $\mathrm{MnSO}_{4}$ & $\mathrm{MnSO}_{4}$ & Dissolve & $6.96 \times 10^{-5}$ \\
\hline Morenosite & $\mathrm{NiSO}_{4} \cdot 7 \mathrm{H}_{2} \mathrm{O}$ & Dissolve & $3.08 \times 10^{-5}$ \\
\hline Pyrite & $\mathrm{FeS}_{2}$ & Dissolve & $3.62 \times 10^{-5}$ \\
\hline $\mathrm{ZnSO}_{4} \cdot \mathrm{H}_{2} \mathrm{O}$ & $\mathrm{ZnSO}_{4} \cdot \mathrm{H}_{2} \mathrm{O}$ & Dissolve & $1.84 \times 10^{-5}$ \\
\hline
\end{tabular}

\begin{tabular}{|l|c|c|}
\hline \multicolumn{3}{|c|}{$\begin{array}{c}\text { TABLE 4 } \\
\text { Composition of analysed sulphuric acid leachate versus } \\
\text { modelled sulphuric solution (units for elements in } \\
\text { molality) }\end{array}$} \\
\hline Analyte & 3.6 & Simulated \\
\hline $\mathrm{pH}$ & 7.45 & 3.416 \\
\hline $\mathrm{pe}$ & $5.87 \times 10^{-3}$ & 8.05 \\
\hline Ionic strength & $1.00 \times 10^{-4}$ & $6.04 \times 10^{-3}$ \\
\hline $\mathrm{Al}$ & $4.25 \times 10^{-4}$ & $1.00 \times 10^{-4}$ \\
\hline $\mathrm{Ca}$ & $3.00 \times 10^{-6}$ & $4.25 \times 10^{-4}$ \\
\hline $\mathrm{Cu}$ & $5.38 \times 10^{-4}$ & $3.00 \times 10^{-6}$ \\
\hline $\mathrm{Fe}$ & $1.04 \times 10^{-5}$ & $5.43 \times 10^{-4}$ \\
\hline $\mathrm{K}$ & $3.78 \times 10^{-4}$ & $8.22 \times 10^{-6}$ \\
\hline $\mathrm{Mg}$ & $6.96 \times 10^{-5}$ & $3.77 \times 10^{-4}$ \\
\hline $\mathrm{Mn}$ & $1.67 \times 10^{-5}$ & $6.96 \times 10^{-5}$ \\
\hline $\mathrm{Na}$ & $3.08 \times 10^{-5}$ & $1.67 \times 10^{-5}$ \\
\hline $\mathrm{Ni}$ & $1.79 \times 10^{-3}$ & $3.08 \times 10^{-5}$ \\
\hline $\mathrm{S}$ & $2.60 \times 10^{-6}$ & $1.86 \times 10^{-3}$ \\
\hline $\mathrm{Si}$ & $4.49 \times 10^{-6}$ & $2.60 \times 10^{-6}$ \\
\hline $\mathrm{U}$ & $1.84 \times 10^{-5}$ & $4.49 \times 10^{-6}$ \\
\hline $\mathrm{Zn}$ & & $1.84 \times 10^{-5}$ \\
\hline
\end{tabular}




\section{CONCLUSION}

The study has shown that gold tailings have potential to release metals to the surrounding soils and water systems. The role of rainwater in the leaching of metals and sulphates is clear and leaching experiments were used to determine the host of metals that could be released by rainwater. These processes were successfully simulated using geochemical modelling, making this an important tool for complementing experimental techniques. Given the initial and final leachate solutions, it was possible to determine which minerals were of relevance in the leaching process. There was good correlation between experimental and simulated solutions in both cases. Even though the exact mineralogy of the tailings was not entirely known, the models showed that it is possible to determine the quantity of theoretical reactive minerals present in the tailings samples. From these results, it could be possible to estimate the metal load of readily soluble mineral phases present on the surface of the tailings and that could be released following continued leaching by rainwater. This method could ultimately be implemented in environmental risk assessment studies.

\section{ACKNOWLEDGEMENTS}

This work was supported by the US National Academy of Sciences (grant no. AID-OAA-A-11-00012) and the South African National Research Foundation. The authors thank Mr Thuthuka Mabaso for his assistance with ICP-OES and $\mathrm{Mr}$ Bongani Yalala for his assistance with sampling. The authors also thank the two reviewers for their contributions which greatly improved the content of this article.

\section{REFERENCES}

BAKATULA E, CUKROWSKA E, CHIMUKA L and TUTU H (2012) Characterization of cyanide in a natural stream impacted by gold mining activities in the Witwatersrand Basin, South Africa. Toxicol. Environ. Chem. 94 (1) 7-19. http://dx.doi.org/10.1080/0277 2248.2011.638637

BLOWES DW, PTACEK CJ, JAMBOR JL and WEISENER CG (2003) The geochemistry of acid mine drainage. In: Holland HD and Turekian KK (eds.) Treatise on Geochemistry. Elsevier, Oxford.

CAMDEN-SMITH B, JOHNSON R, RICHARDSON R, BILLING D and TUTU H (2013) Investigating the potential impact of efflorescent mineral crusts on water quality: complementing analytical techniques with geochemical modelling. In Brown A, Figueroa L, and Wolkersdorfer Ch (eds.), Reliable Mine Water Technology (Vol I). Publication Printers, Denver, Colorado.

COCKSEDGE JL (1988) The design and production of synthetic rainwater samples. Warren Spring Laboratory, Stevenage. $17 \mathrm{pp}$

CRAWFORD J (1999) Geochemical Modelling - A Review of Current
Capabilities and Future Directions. PhD Thesis, Royal Institute of Technology, Stockholm.

CUKROWSKA EM, GOVENDER K and VILJOEN M (2004) Ion mobility based on column leaching of South African gold tailings dam with chemometric evaluation. Chemosphere 56 (1) 39-50. http://dx.doi.org/10.1016/j.chemosphere.2004.01.036

GROVER BPC, MTHOMBENI P and TUTU H (2015) Fractionation of metals in gold mine tailings: implications for release and mobility to the surroundings. PhD thesis, University of the Witwatersrand.

HAGEMAN PL (2007) U.S. Geological Survey field leach test for assessing water reactivity and leaching potential of mine wastes, soils, and other geologic and environmental materials. In: U.S. Geological Survey Techniques and Methods, Book 5. U.S. Geological Survery, Virginia

NENGOVHELA AC, YIBAS B and OGOLA JS (2006) Characterisation of gold tailings dams of the Witwatersrand Basin with reference to their acid mine drainage potential, Johannesburg, South Africa. Water SA 32 (4) 499-506.

JAMBOR JL, NORDSTROM DK and ALPERS CN (2000) Metal-sulfate salts from sulfide mineral oxidation. Rev. Mineral. Geochem. 40 (1) 303-350.

NORDSTROM DK and SOUTHAM G (1997) Geomicrobiology of sulfide mineral oxidation. Rev. Mineral. 35 361-390.

NORDSTROM DK and CAMPBELL KM (2014) Modeling LowTemperature Geochemical Processes. In: Holland HD and Turekian KK (eds.) Treatise on Geochemistry ( $2^{\text {nd }}$ edn). Elsevier, Oxford.

PARKHURST D and APPELO C (2013) Description of input and examples for PHREEQC version 3-A computer program for speciation, batch-reaction, one-dimensional transport, and inverse geochemical calculations. U.S. Geological Survey Techniques and Methods. 497 pp. http://pubs.usgs.gov/tm/06/a43/ (Accessed 2 February 2015).

RAURET G, LOPEZ-SANCHEZ JF, SAHUQUILLO A, RUBIO R, DAVIDSON C, URE A and QUEVAUVILLER P (1999) Improvement of the BCR three step sequential extraction procedure prior to the certification of new sediment and soil reference materials. J. Environ. Monit. 1 (1) 57-61 http://dx.doi.org/10.1039/ a807854h

ŠRÁČEK O, ČERNÍK M and VENCELIDES Z (2013) Applications of Geochemical and Reactive Transport Modeling in Hydrogeology $\left(1^{\text {st }}\right.$ edn). Palacký University, Olomouc, Czech Republic.

STUMM W and MORGAN J (1996) Aquatic Chemistry: Chemical Equilibria in Natural Waters. John Wiley \& Sons, New York.

TUTU H (2006) Determination and geochemical modelling of the dispersal of uranium in gold mine polluted land on the Witwatersrand Basin. PhD thesis, University of the Witwatersrand.

TUTU H, MCCARTHY TS and CUKROWSKA EM (2008) The chemical characteristics of acid mine drainage with particular reference to sources, distribution and remediation: The Witwatersrand Basin, South Africa, as a case study. Appl. Geochem. 23 (12) 3666-3684. http://dx.doi.org/10.1016/j.apgeochem.2008.09.002

ZHU C and ANDERSON G (2002) Environmental Applications of Geochemical Modeling. The Press Syndicate of the University of Cambridge, Cambridge, United Kingdom. http://dx.doi. org/10.1017/CBO9780511606274 